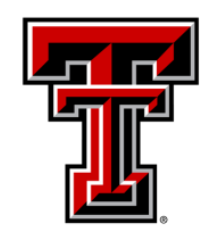

TEXAS TECH UNIVERSITY

Libraries"

\title{
AtMOSPHERIC CARBON AND TRANSPORT - AMERICA (ACT-AMERICA) DATA SETS: DESCRIPTION, MANAGEMENT, AND DELIVERY
}

\section{The Texas Tech community has made this publication openly available. Please share how this access benefits you. Your story matters to us.}

\begin{tabular}{|l|l|}
\hline Citation & $\begin{array}{l}\text { Wei, Y., Shrestha, R., Pal, S., Gerken, T., Feng, S., McNelis, J., et al. } \\
\text { (2021). Atmospheric Carbon and Transport - America (ACT- } \\
\text { America) data sets: Description, management, and delivery. Earth } \\
\text { and Space Science, 8, e2020EA001634. } \\
\text { https://doi.org/10.1029/2020EA001634 }\end{array}$ \\
\hline Citable Link & $\underline{\text { https://hdl.handle.net/2346/88123 }}$ \\
\hline Terms of Use & $\underline{\text { CC BY-NC-ND 4.0 }}$ \\
\hline
\end{tabular}




\section{Earth and Space Science}

\section{TECHNICAL REPORTS: DATA}

10.1029/2020EA001634

\section{Special Section: \\ Carbon Weather: Toward the next generation of regional greenhouse gas inversion systems}

\section{Key Points:}

- Atmospheric Carbon and Transport - America (ACT-America) provides a unique, weather-oriented collection of atmospheric $\mathrm{CO}$, $\mathrm{CH} 4$, trace gases, and meteorological properties measurements

- ACT-America data are free and open to the public from the Oak Ridge National Laboratory Distributed Active Archive Center (ORNL DAAC)

- ACT-America data are uniquely suited to improve the accuracy and precision of regional inverse greenhouse gas (GHG) flux estimates

\section{Supporting Information:}

Supporting Information may be found in the online version of this article.

Correspondence to:

Y. Wei,

weiy@ornl.gov

\section{Citation:}

Wei, Y., Shrestha, R., Pal, S., Gerken, T., Feng, S., McNelis, J., et al. (2021). Atmospheric Carbon and Transport - America (ACT-America) data sets: Description, management, and delivery. Earth and Space Science, 8, e2020EA001634. https://doi. org/10.1029/2020EA001634

\section{Received 30 DEC 2020} Accepted 9 MAY 2021

(c) 2021. The Authors. Earth and Space Science published by Wiley Periodicals LLC on behalf of American Geophysical Union.

This is an open access article under the terms of the Creative Commons Attribution-NonCommercial-NoDerivs License, which permits use and distribution in any medium, provided the original work is properly cited, the use is non-commercial and no modifications or adaptations are made.

\section{Atmospheric Carbon and Transport - America (ACT- America) Data Sets: Description, Management, and Delivery}

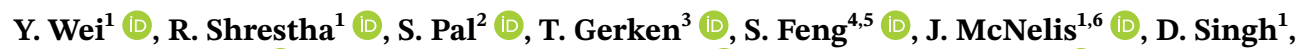
M. M. Thornton ${ }^{1}$ (D) A. G. Boyer, ${ }^{1,7}$, M. A. $\operatorname{Shook}^{8}$ (D, G. Chen ${ }^{8}$, B. C. Baier ${ }^{9}$ (D), Z. R. Barkley ${ }^{4}$ (D) J. D. Barrick ${ }^{10}$, J. R. Bennett ${ }^{11}$, E. V. Browell ${ }^{12}$ (D) J. F. Campbell ${ }^{8}$ (D), L. J. Campbell ${ }^{4}$, Y. Choi $^{10}$ (D) J. Collins ${ }^{10}$, J. Dobler ${ }^{13}$ (D), M. Eckl ${ }^{14}$ (D) A. Fiehn ${ }^{14}$ (D),

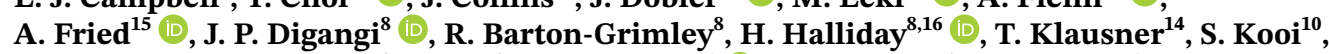
J. Kostinek ${ }^{17}$, T. Lauvaux ${ }^{18}$, B. Lin $^{8}$, M. J. McGill ${ }^{19}$ (D), B. Meadows ${ }^{8}$, N. L. Miles ${ }^{4}$, A. R. Nehrir ${ }^{8}$,

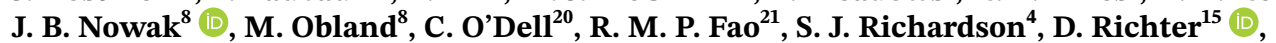
A. Roiger $^{14}$, C. Sweeney ${ }^{22}$ (D) J. Walega ${ }^{15}$, P. Weibring ${ }^{15}$, C. A. Williams ${ }^{23}$ (D) M. M. Yang ${ }^{14}$, Y. Zhou ${ }^{23}$ (i), and K. J. Davis ${ }^{4,24}$ (D)

${ }^{1}$ Environmental Sciences Division, Oak Ridge National Laboratory, Oak Ridge, TN, USA, ${ }^{2}$ Department of Geosciences, Atmospheric Science Division, Texas Tech University, Lubbock, TX, USA, ${ }^{3}$ School of Integrated Sciences, James Madison University, Harrisonburg, VA, USA, ${ }^{4}$ Department of Meteorology and Atmospheric Science, The Pennsylvania State University, University Park, PA, USA, ${ }^{5}$ Now at Pacific Northwest National Laboratory, Richland, WA, USA, ${ }^{6}$ Now at Jet Propulsion Laboratory, Los Angeles, CA, USA, ${ }^{7}$ Now at Reviewbox, Knoxville, TN, USA, ${ }^{8}$ NASA Langley Research Center, Hampton, VA, USA, ${ }^{9}$ Cooperative Institute for Research in Environmental Sciences, University of Colorado Boulder and NOAA Global Monitoring Laboratory, Boulder, CO, USA, ${ }^{10}$ Science Systems \& Applications, Inc., NASA Langley Research Center, Hampton, VA, USA, ${ }^{11}$ Bay Area Environmental Research Institute, Moffett Field, CA, USA, ${ }^{12}$ STARSS-III Affiliate, NASA Langley Research Center, Hampton, VA, USA, ${ }^{13}$ Spectral Sensor Solutions LLC, Fort Wayne, IN, USA, ${ }^{14}$ Deutsches Zentrum für Luft- und Raumfahrt (DLR), Institut für Physik der Atmosphäre, Bavaria, Germany, ${ }^{15}$ Institute of Arctic and Alpine Research INSTAAR, University of Colorado, Boulder, CO, USA, ${ }^{16}$ Now at U.S. Environmental Protection Agency, Washington, D.C, USA, ${ }^{17}$ Institute of Atmospheric Physics, German Aerospace Center, Mecklenburg-Vorpommern, Germany, ${ }^{18}$ Laboratory for Sciences of Climate and Environment, Paris, France, ${ }^{19}$ Earth Sciences Division, NASA Goddard Space Flight Center, Greenbelt, MD, USA, ${ }^{20}$ Cooperative Institute for Research in the Atmosphere, Colorado State University, Fort Collins, CO, USA, ${ }^{21}$ Science Systems \& Applications, Inc., NASA Goddard Space Flight Center, Greenbelt, MD, USA, ${ }^{22}$ NOAA Global Monitoring Laboratory, Boulder, CO, USA, ${ }^{23}$ Graduate School of Geography, Clark University, Worcester, MA, USA, ${ }^{24}$ Earth and Environmental Systems Institute, The Pennsylvania State University, University Park, PA, USA

Abstract The ACT-America project is a NASA Earth Venture Suborbital-2 mission designed to study the transport and fluxes of greenhouse gases. The open and freely available ACT-America data sets provide airborne in situ measurements of atmospheric carbon dioxide, methane, trace gases, aerosols, clouds, and meteorological properties, airborne remote sensing measurements of aerosol backscatter, atmospheric boundary layer height and columnar content of atmospheric carbon dioxide, tower-based measurements, and modeled atmospheric mole fractions and regional carbon fluxes of greenhouse gases over the Central and Eastern United States. We conducted 121 research flights during five campaigns in four seasons during 2016-2019 over three regions of the US (Mid-Atlantic, Midwest and South) using two NASA research aircraft (B-200 and C-130). We performed three flight patterns (fair weather, frontal crossings, and OCO-2 underflights) and collected more than 1,140 $\mathrm{h}$ of airborne measurements via level-leg flights in the atmospheric boundary layer, lower, and upper free troposphere and vertical profiles spanning these altitudes. We also merged various airborne in situ measurements onto a common standard sampling interval, which brings coherence to the data, creates geolocated data products, and makes it much easier for the users to perform holistic analysis of the ACT-America data products. Here, we report on detailed information of data sets collected, the workflow for data sets including storage and processing of the quality controlled and quality assured harmonized observations, and their archival and formatting for users. Finally, we provide some important information on the dissemination of data products including metadata and highlights of applications of ACT-America data sets. 
Plain Language Summary We describe the data collected and produced by the Atmospheric Carbon and Transport - America mission, including airborne and tower-based measurements of greenhouse gases (e.g., carbon dioxide and methane) and modeled atmospheric mole fractions and regional carbon fluxes of greenhouse gases over North America. In this paper, we briefly describe the data collections and archival including the instruments and methodology used to generate, manage, and distribute the data, and the significance of these new measurements for the study of the North American carbon cycle.

\section{Introduction}

The ACT-America (Atmospheric Carbon and Transport-America) project is a NASA Earth Venture Suborbital-2 mission designed to study the atmospheric transport and surface fluxes of greenhouse gases (GHGs), including atmospheric carbon dioxide $\left(\mathrm{CO}_{2}\right)$ and methane $\left(\mathrm{CH}_{4}\right)$, across the eastern United States. Its overarching goal is to improve the accuracy and precision of regional inverse flux estimates of GHGs. This overarching goal is being pursued via three specific objectives: (a) quantification and reduction of uncertainty in simulations of atmospheric carbon (C) transport, (b) quantification and reduction in uncertainty in prior $\mathrm{C}$ flux estimates, and (c) evaluation of the ability of the Orbiting Carbon Observatory - 2 (OCO-2) instrument (Eldering et al., 2017) to capture regional-scale, tropospheric gradients in column $\mathrm{CO}_{2}\left(\mathrm{XCO}_{2}\right)($ Davis et al., 2021). Extensive atmospheric transport and biological flux modeling complement the observational data to achieve ACT-America's research goals.

This paper reports detailed information for the different types of data sets collected and produced within the ACT-America project, including their quality-assurance and quality-control (QA/QC) procedure, the workflow for data sets including storage and processing of the harmonized observations, and their archival and formatting for users. It also provides some important information on the dissemination of data products including metadata and highlights of applications of data sets for future investigations. The final data sets, including all observational data and selected results from numerical simulations, collected and produced by the ACT-America project have been or will be archived and published for free and public access at the Oak Ridge National Laboratory Distributed Active Archive Center (ORNL DAAC).

\subsection{Airborne Measurements}

ACT-America flight campaigns collected in situ and lidar remote sensing measurements of GHGs, tracers and meteorological variables across a variety of continental surfaces and atmospheric conditions over three regions of the US (Mid-Atlantic, Midwest, and South), which were defined according to flight base and selected to encompass weather patterns and $\mathrm{C}$ fluxes typical of the central and eastern US. Two aircraft were deployed, the NASA Langley Beechcraft B-200 King Air and the NASA Wallops Flight Facility Lockheed C-130 Hercules. The B-200 is a twin-turboprop research aircraft that typically supports 4,100 lbs of payload, $4 \mathrm{~h}$ of duration, and $800 \mathrm{Nmi}$ range. The $\mathrm{C}-130$ is a four-engine turboprop aircraft designed for maximum payload capacity $(36,000 \mathrm{lbs})$. It is equipped with external fuel tanks to increase flight range (3,200 Nmi) and duration $(10 \mathrm{~h})$. See Figure S1 for photos of these two aircraft. Both aircraft carried a common suite of instruments measuring atmospheric $\mathrm{C}$ mole fractions, atmospheric $\mathrm{C}$ tracers, meteorological variables, and navigational data (e.g., aircraft position, attitude, and speed). The C-130's larger payload capacity also allowed it to carry additional instruments, including the in situ ethane $\left(\mathrm{C}_{2} \mathrm{H}_{6}\right)$ and nitrous oxide $\left(\mathrm{N}_{2} \mathrm{O}\right)$ gases analyzer (i.e., Quantum Cascade Laser Spectrometer, QCLS) and lidar instruments to measure column $\mathrm{CO}_{2}\left(\mathrm{XCO}_{2}\right)$ and column $\mathrm{CH}_{4}\left(\mathrm{XCH}_{4}\right)$ and detect clouds and clear-air atmospheric structure including the atmospheric boundary layer (ABL) depth. Table 1 lists the specific instruments deployed in each aircraft, parameters measured, and sampling frequencies.

The ACT-America mission conducted research flights (RFs) in all Northern Hemisphere seasons through five campaigns (Figure 1; Table 2) in order to sample seasonal variations in GHG fluxes and weather. Flights encompassed regions of a few hundred to one thousand kilometers in extent guided by detailed 
weather forecasting and nowcasting. Flights targeted midday, well-mixed ABL conditions and were typically conducted during late morning through mid-afternoon hours. Flights were conducted at this time to enable ready sampling of the direct impact of surface fluxes of GHGs on the atmosphere-and this occurs within the ABL-and sampling within the shallow, stable ABL characteristic of nighttime conditions with aircraft is difficult. In each RF, both aircraft (unless one was under maintenance) flew in a coordinated pattern to provide better spatial and altitude coverage within a short time window, with the B-200 mainly focusing on the mid-troposphere and $\mathrm{ABL}$, and the $\mathrm{C}-130$ covering the upper and lower free troposphere (UFT and LFT), plus additional ABL sampling when needed, enabled by its greater flight range (Figure 2). Flights targeted typical weather conditions including high-pressure, fair-weather conditions, and the passage of mid-latitude cyclones. Furthermore, $12 \mathrm{RFs}$ were conducted in the first four seasonal campaigns (three in each season) to sample atmospheric $\mathrm{CO}_{2}$ distributions along roughly $500 \mathrm{~km}$ along the track of OCO-2 passes (denoted as OCO-2 underflight). Bell et al. (2020) provided details on the underflight tracks and results pertaining to intercomparison between lidar-derived and OCO-2 retrieved $\mathrm{XCO}_{2}$ measurements.

Table 1

Overview of Instruments Deployed on ACT-America Flight Campaigns

\begin{tabular}{|c|c|c|c|c|c|c|}
\hline Type & Instrument name & Instrument description & Parameters measured & Sampling frequency & Aircraft & Campaigns \\
\hline \multirow[t]{5}{*}{$\begin{array}{l}\text { In situ continuous } \\
\text { gas sensor }\end{array}$} & \multirow[t]{2}{*}{ PICARRO CRDS } & $\begin{array}{l}\text { - In situ trace gas analyzer } \\
\text { - Measurement technique: } \\
\text { Infrared Cavity Ring-Down } \\
\text { Spectroscopy (CRDS) } \\
\text { - Model: PICARRO G2401-m }\end{array}$ & $\begin{array}{c}\text { Mole fraction of } \mathrm{CO}_{2}, \mathrm{CH}_{4} \\
\text { and } \mathrm{CO} \text { in dry air }\end{array}$ & $0.4 \mathrm{~Hz}$ & C-130; B-200 & All \\
\hline & & $\begin{array}{l}\text { - In situ trace gas analyzer } \\
\text { - Measurement technique: } \\
\text { Infrared CRDS } \\
\text { - Model: PICARRO G2301-m }\end{array}$ & $\begin{array}{l}\text { Mixing ratio of water } \\
\text { vapor, and mole } \\
\text { fraction of } \mathrm{CO}_{2} \text { and } \\
\mathrm{CH}_{4} \text { in dry air }\end{array}$ & $1 \mathrm{~Hz}$ & $\mathrm{C}-130$ & $\begin{array}{l}\text { All (except } \\
\text { Summer } \\
\text { 2016) }\end{array}$ \\
\hline & Ozone & $\begin{array}{l}\text { - Continuous Ozone }\left(\mathrm{O}_{3}\right) \\
\text { monitor } \\
\text { - Measurement technique: } \\
\text { dual beam UV absorption } \\
\text { spectroscopy } \\
\text { - Model: } 2 \mathrm{~B} \text { Technologies } \\
\text { Model } 205\end{array}$ & $\begin{array}{c}\text { Mole fraction of } \mathrm{O}_{3} \text { in } \\
\text { total air }\end{array}$ & $0.5 \mathrm{~Hz}$ & C-130; B-200 & All \\
\hline & CAMS-2 & $\begin{array}{l}\text { - Compact Atmospheric } \\
\text { Multi-species Spectrometer } \\
\text { (CAMS-2) } \\
\text { - Measurement technique: } \\
\text { Laser spectrometer } \\
\text { - Reference: Weibring } \\
\text { et al., } 2020\end{array}$ & $\begin{array}{c}\text { Mole fraction of } \mathrm{C}_{2} \mathrm{H}_{6} \text { in } \\
\text { total air }\end{array}$ & $1 \mathrm{~Hz}$ & B-200 & $\begin{array}{l}\text { All (limited } \\
\text { data } \\
\text { during } \\
\text { Summer } \\
2016 \\
\text { campaign) }\end{array}$ \\
\hline & QCLS & $\begin{array}{l}\text { - Quantum Cascade Laser } \\
\text { Spectrometer (QCLS) } \\
\text { - Measurement technique: } \\
\text { Laser spectrometer } \\
\text { - Reference: Kostinek } \\
\text { et al., } 2019\end{array}$ & $\begin{array}{l}\text { Mole fraction of } \mathrm{C}_{2} \mathrm{H}_{6} \text { and } \\
\mathrm{N}_{2} \mathrm{O} \text { in dry air }\end{array}$ & $2 \mathrm{~Hz}$ & $\mathrm{C}-130$ & $\begin{array}{l}\text { Fall 2017; } \\
\quad \text { Summer } \\
\quad 2019\end{array}$ \\
\hline $\begin{array}{l}\text { In situ flask gas } \\
\text { sampler }\end{array}$ & PFP & $\begin{array}{l}\text { NOAA Programmable } \\
\text { Flask Package (PFP) } \\
\text { - Measurement technique: } \\
\text { Whole-air flask sampler } \\
\text { - Reference: Baier } \\
\text { et al., 2020; Sweeney } \\
\text { et al., 2015; Sweeney } \\
\text { et al., } 2018\end{array}$ & $\begin{array}{c}\text { Dry air mole fractions } \\
\text { of } \sim 50 \text { trace species } \\
\text { including } \mathrm{CO}_{2}, \mathrm{CH}_{4} \text {, } \\
\mathrm{CO}, \mathrm{N}_{2} \mathrm{O} \text {, sulfur } \\
\text { hexafluoride }\left(\mathrm{SF}_{6}\right), \\
\text { select halocarbons, } \\
\text { hydrocarbons, and } \\
\text { sulfur-containing } \\
\text { species, and isotopic } \\
\text { ratios of } \mathrm{CO}_{2} \text { and } \mathrm{CH}_{4}\end{array}$ & $\begin{array}{l}\sim 12 \text { discrete samples } \\
\text { per aircraft per } \\
\text { flight }\end{array}$ & C-130; B-200 & All \\
\hline
\end{tabular}


Table 1

Continued

\begin{tabular}{|c|c|c|c|c|c|c|}
\hline Type & Instrument name & Instrument description & Parameters measured & Sampling frequency & Aircraft & Campaigns \\
\hline \multirow[t]{4}{*}{$\begin{array}{l}\text { Remote sensing } \\
\quad \text { Lidar }\end{array}$} & MFLL & $\begin{array}{l}\text { - Multifunctional Fiber Laser } \\
\text { Lidar (MFLL) } \\
\text { - Measurement technique: } \\
\text { Intensity-Modulated } \\
\text { Continuous-Wave (IM-CW) } \\
\text { lidar } \\
\text { - Reference: Campbell } \\
\text { et al., 2020; Dobler } \\
\text { et al., 2013; Lin et al., } 2018\end{array}$ & $\begin{array}{c}\mathrm{CO}_{2} \text { column density, } \\
\text { range to the } \\
\text { surface, and surface } \\
\text { reflectance }\end{array}$ & $10 \mathrm{~Hz}$ & C-130 & $\begin{array}{l}\text { All (except } \\
\text { Summer } \\
\text { 2019) }\end{array}$ \\
\hline & ACES & $\begin{array}{l}\text { ASCENDS CarbonHawk } \\
\text { Experiment Simulator } \\
\text { (ACES). ACES is similar } \\
\text { to MFLL. But ACES uses } \\
\text { three apertures (v.s. One for } \\
\text { MFLL) and has more lasers } \\
\text { (3) for higher power. } \\
\text { - Measurement technique: } \\
\text { IM-CW lidar } \\
\text { - Reference: Obland } \\
\text { et al., } 2015\end{array}$ & & & & \\
\hline & CPL & $\begin{array}{l}\text { - Cloud Physics Lidar (CPL) } \\
\text { - Measurement technique: } \\
\text { Backscatter lidar } \\
\text { - Reference: McGill } \\
\text { et al. } 2002\end{array}$ & $\begin{array}{l}\text { Atmospheric layers, } \\
\text { cloud height and } \\
\text { fractional cover, and } \\
\text { atmospheric boundary } \\
\text { layer (ABL) depth (Pal } \\
\text { et al., 2020b) }\end{array}$ & $\begin{array}{c}0.25 \mathrm{~Hz}, 30 \mathrm{~m} \text { vertical } \\
\text { resolution }\end{array}$ & & \\
\hline & HALO & $\begin{array}{l}\text { High Altitude Lidar } \\
\text { Observatory (HALO) } \\
\text { - Measurement technique: } \\
\text { Differential absorption } \\
\text { lidar and high spectral } \\
\text { resolution lidar } \\
\text { - Reference: Nehrir } \\
\text { et al., } 2018\end{array}$ & $\begin{array}{c}\mathrm{CH}_{4} \text { column density, } \\
\text { aerosol properties, } \\
\text { atmospheric layers, } \\
\text { cloud cover and } \\
\text { fraction, and } \mathrm{ABL} \\
\text { depth }\end{array}$ & $0.1 \mathrm{~Hz}$ & & Summer 2019 \\
\hline $\begin{array}{l}\text { In situ continuous } \\
\text { meteorological } \\
\text { sensors }\end{array}$ & MIS & $\begin{array}{l}\text { Meteorological Instrument } \\
\text { Suite (MIS) } \\
\text { Models: Honeywell } \\
\text { Precision Pressure } \\
\text { Transducer (PPT2) pressure } \\
\text { transducer, Rosemount de- } \\
\text { iced total air temperature } \\
\text { probe, and Edgetech } \\
\text { Vigilant } 137 \text { hygrometer } \\
\text { with 3-stage TEC chilled } \\
\text { mirror }\end{array}$ & $\begin{array}{l}\text { Total and static } \\
\text { atmospheric } \\
\text { temperature, dew- } \\
\text { point temperature, } \\
\text { atmospheric pressure } \\
\text { (Davis et al., 2018) }\end{array}$ & $1 \mathrm{~Hz}$ & $\begin{array}{l}\text { C-130; } \\
\text { B-200 }\end{array}$ & All \\
\hline $\begin{array}{l}\text { In situ continuous } \\
\text { navigational } \\
\text { sensors }\end{array}$ & EGI & $\begin{array}{l}\text { Embedded Global } \\
\text { Positioning System/Inertial } \\
\text { Navigation System (EGI) } \\
\text { units } \\
\text { - Models: Honeywell H-764 } \\
\text { on C-130 and Applanix } \\
\text { Model } 510 \text { V5 on B-200; } \\
\text { Differential GPS (Conley } \\
\text { et al., 2014) }\end{array}$ & $\begin{array}{l}\text { Aircraft latitude, } \\
\text { longitude, altitude, } \\
\text { attitude, ground speed, } \\
\text { horizontal winds, etc. }\end{array}$ & $1 \mathrm{~Hz}$ & $\begin{array}{l}\text { C-130; } \\
\text { B-200 }\end{array}$ & All \\
\hline
\end{tabular}


All flight patterns included long level legs in the ABL, LFT, and UFT. Frontal flights typically crossed a front along one line at multiple altitudes. Fair weather flights used either a box pattern to sample atmospheric conditions across relatively homogeneous air masses in and around high-pressure systems, or long transects across the flow generated by the high pressure conditions. Vertical profiles were included within all flight plans, and were used to document local vertical structure including ABL depths (Pal, 2019). Spiral profiles were used for direct comparison to remotely sensed column $\mathrm{CO}_{2}$ and $\mathrm{CH}_{4}$ (e.g., Campbell et al., 2020; Bell et al., 2020). During the five campaigns, a total of $121 \mathrm{RFs}$, more than $1,140 \mathrm{~h}$ of observations, 570 level legs, and 1,363 vertical profiles were conducted using the two aircraft (Table 2; Figure 2).

Figure $1 \mathrm{~g} / \mathrm{h}$ show a RF on 20 June 2019, which sampled GHG structures across a cold front whose location is shown in Figure 1g. The frontal structure was sampled at three altitudes- $300 \mathrm{~m}$ above ground level (AGL) within the ABL and 2-3 km and 6-8 km mean sea level (MSL) for LFT and UFT, respectively. The B-200 flew a triangular pattern measuring the UFT while headed to the northeast, then the ABL and LFT along the long N-S line, and the ABL while returning to the Shreveport flight base from the southeast, providing a long transect of modification of Gulf inflow by coastal industry and ecosystems. The C-130 was able to fly a T-shaped pattern including a long N-S transect across the front at two altitudes. The C-130 took one pass in the UFT, measuring atmospheric layers and $\mathrm{XCH}_{4}$ with lidar (HALO), as well as in situ data, and another pass within the ABL, sampling directly the changes in atmospheric GHGs within these contrasting air masses.

More detailed description of the overall ACT-America flight patterns and design of the synoptic sequences is provided in Davis et al. (2021). The ACT-America flight catalog (Pal \& Davis, 2021) provides detailed information about the scientific objectives of each flight, the weather conditions and GHG environment, instrument status, flight paths, and quicklooks of the measurements of each RF. In sum, these multi-season, multi-regional observations represent a unique and unprecedented contribution to the understanding of North American terrestrial carbon fluxes and their intersection with synoptic weather.

\subsection{Tower-Based GHG Measurements}

Data were also collected on a network of instrumented communications towers within the ACT-America sampling domain. 11 towers were deployed to spatially complement the routine long-term tower measurements of the NOAA Global Greenhouse Gas Reference Network (GGGRN; Andrews et al., 2014). Figure $1 \mathrm{f}$ shows the location of these 11 towers along with current active GGGRN sites (including in situ towers and airborne flasks) within the central and eastern US (see Table S1 for site coordinates and measurement height). Tower-based instruments measured GHGs mole fractions continuously at about 100m AGL using the Picarro G2301 CRDS. Tower-based measurements began in early 2015 and continued through 2019. Data from 11 towers are provided, although not all towers have data from all years (Miles et al., 2018; Miles et al., 2020). Calibration and uncertainty quantification procedures used for tower-based GHG measurements are provided in Text S1. These measurements are an essential input to long-term diagnoses of the continental carbon balance and inverse flux estimates (e.g., Peters et al., 2007; Hu et al., 2019). The aircraft flights are spatially rich and designed to complement the temporally rich but spatially sparse tower network. Daily, automated data transfer from the towers to Pennsylvania State University (PSU) was allowed for remote monitoring of instrument status and flight planning.

\section{Airborne and Tower Data Processing and Management}

The ACT-America data management lifecycle involved efforts from many investigators, including the individual instrument teams, data managers at the NASA Langley Research Center (LaRC) field data repository, and staff at the NASA-sponsored ORNL DAAC. The team worked together to develop a detailed data management plan before any data were collected, and continued to communicate regularly throughout the data collection, curation, archival, and publication process.

\subsection{Data Calibration and $\mathrm{QA} / \mathrm{QC}$}

During the field campaigns, the individual instrument teams collected data and performed quick QA/QC checks and processing using initial calibrations to produce preliminary data, which were used for flight plan- 


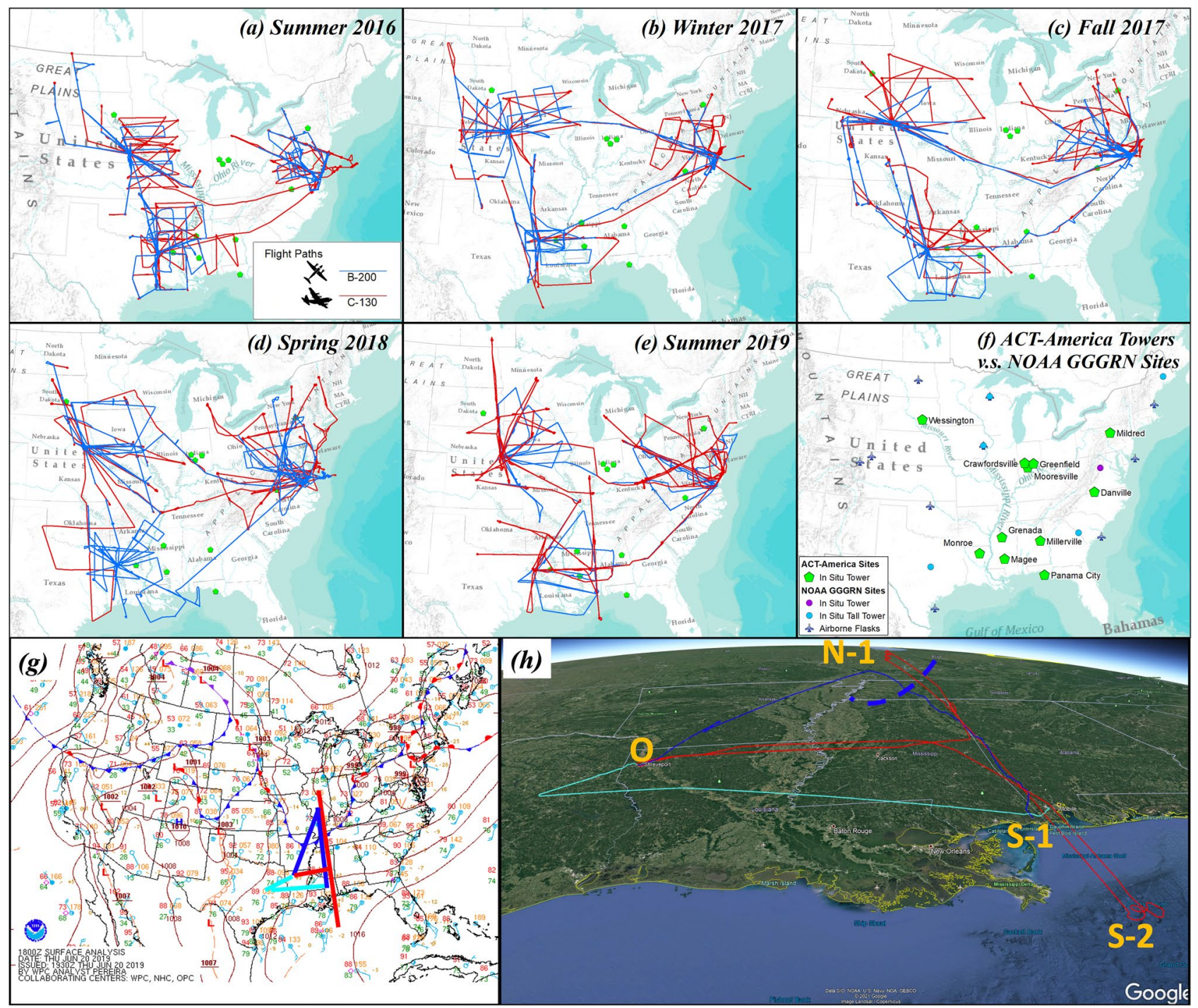

Figure 1. Panel (a)-(e): Flight paths of the B-200 (blue) and C-130 (red) aircraft during the five Atmospheric Carbon and Transport - America (ACT-America) field campaigns spanning four seasons. Measurements from aircraft were complemented with measurements of greenhouse gases (GHGs) from communication towers (green pentagons), deployed to complement the NOAA GGGRN. Panel (f) shows the location of 11 ACT-America towers along with current active GGGRN sites (including in situ towers and airborne flasks). (g) Synoptic setup at 18:00 UTC on 2019-06-20 during the frontal crossing flights. Overlaid lines mark the approximate flight tracks (red: C-130, blue and cyan: B-200 flight tracks during sortie 1 and 2, i.e., before and after refueling). (h) Map of flight tracks of both aircraft overlaid on Google Earth image (short dashed blue curve line marks the approximate cold front boundary).

Table 2

Overview of ACT-America Flight Campaigns and Sampling Intensity in Each Campaign

\begin{tabular}{lccccc}
\hline $\begin{array}{l}\text { Flight } \\
\text { campaign }\end{array}$ & Date & $\begin{array}{c}\text { Number of research } \\
\text { flights (RFs) }\end{array}$ & $\begin{array}{c}\text { Hours of } \\
\text { observations }\end{array}$ & $\begin{array}{c}\text { Number of } \\
\text { level legs }\end{array}$ & $\begin{array}{c}\text { Number of } \\
\text { atmospheric profiles }\end{array}$ \\
\hline Summer 2016 & Jul. 15 to Aug. 28 2016 & 26 & 263.1 & 150 & 270 \\
Winter 2017 & Jan. 30 to Mar. 10 2017 & 27 & 215.6 & 120 & 220 \\
Fall 2017 & Oct. 3 to Nov. 13 2017 & 23 & 228.5 & 100 & 295 \\
Spring 2018 & Apr. 12 to May 20 2018 & 26 & 231.4 & 120 & 334 \\
Summer 2019 & Jun. 17 to Jul. 27 2019 & 19 & 202.1 & 80 & 244 \\
\hline
\end{tabular}



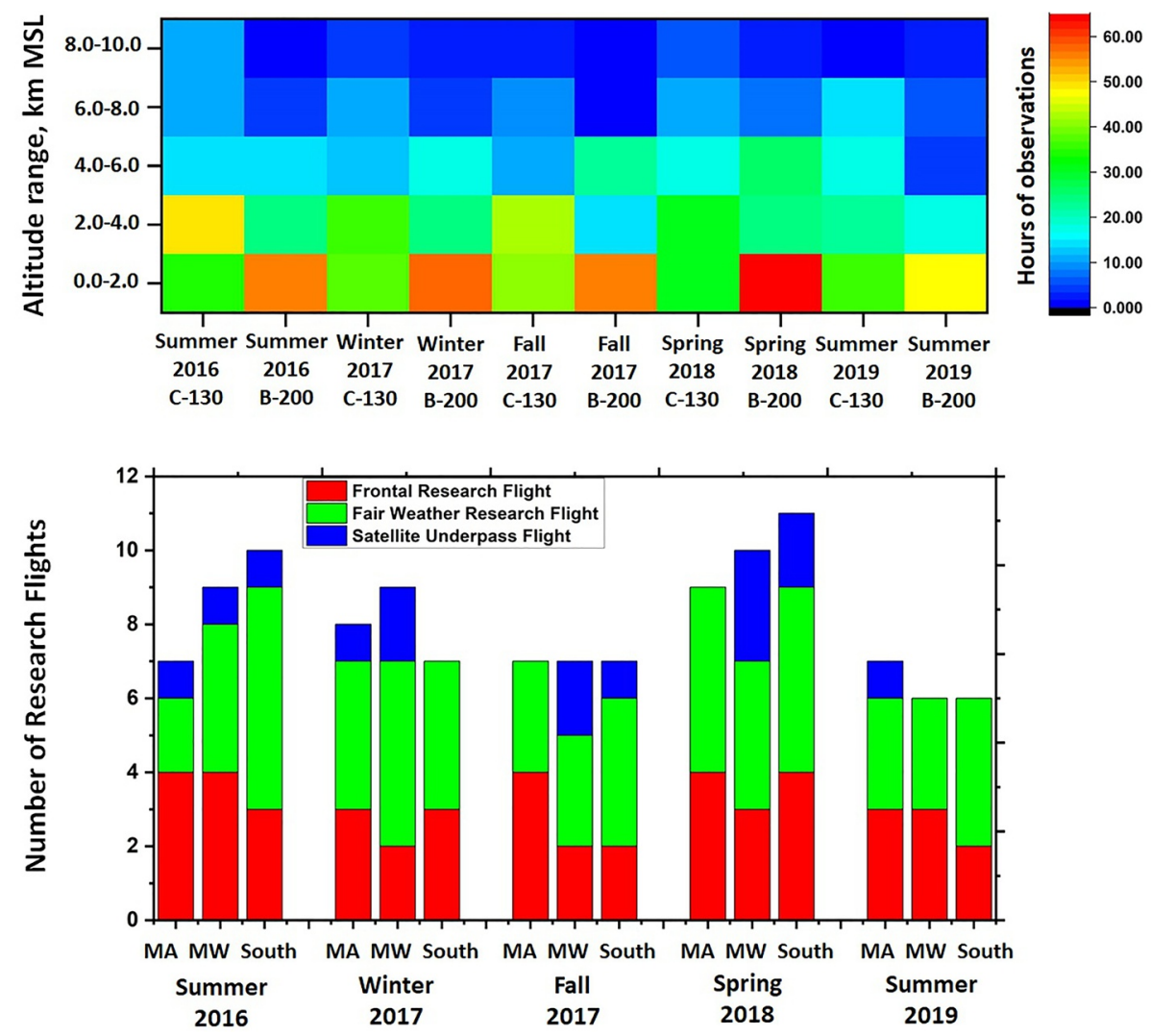

Figure 2. Sampling intensity of the B-200 and C-130 aircraft during the five ACT-America field campaigns. Color table in the upper panel indicates hours of observations for each $2 \mathrm{~km}$ levels. The aircraft sampled air masses from 0 to $10 \mathrm{~km}$ altitude (top panel) and in a variety of weather conditions (bottom panel) in the Mid-Atlantic (MA), Midwest (MW), and South regions of the United States. Three different flight patterns (frontal, fair-weather and OCO-2 underflight) were conducted during the field campaigns (lower panel). The black dotted vertical grid lines in the upper panel separate the field campaigns in different seasons in 2016-2019.

ning, assessing instrument operations, and determining progress in achieving the overall project sampling strategy. After the completion of each campaign, the instrument teams performed their full data processing (e.g., applying final calibrations and measurement synchronization) and more rigorous QA/QC process to generate publication-quality data. A summary of the calibration and QA/QC procedures used by the major instruments and measurements of ACT-America is provided in Text S1. Data may be revised even after this point; for example, as instrument issues are revealed through additional analysis, as new trace gas calibration scales are adopted, or because the processing depends on final data from another instrument team.

\subsection{Data Management at the LaRC Field Data Repository}

The goal of the field data repository is to facilitate data exchange within the science team so that they can efficiently generate publication-quality data products. The ACT-America field data repository was operated by the Suborbital Science Data for Atmospheric Composition (SSD-AC) group at NASA LaRC.

During the campaign periods, the field data repository served several important functions, including hosting the preliminary/quick-look data, providing secure data access for science team members and collaborators, and ensuring that data adhered to standard file naming and format conventions to improve data usability. In situ ACT-America data products are reported in the International Consortium for Atmospheric Research on Transport and Transformation (ICARTT) v1.1 format (Aknan et al., 2013). Raw lidar remote sensing data products are provided in the HDF5 (Hierarchical Data Format 5) format and the derived products (e.g., 
ABL depths) are provided in the ICARTT v1.1 format. The ICARTT file format contains critical metadata including the investigator, variable names and descriptions, estimated measurement uncertainty, missing data and limit of detection flags, a brief instrument description, flight date, and version number, most recent data revision date, and revision history. Files in the ICARTT format were additionally checked against the format standards, particularly when the sampling time stamp is monotonically increasing, no overlaps exist between sampling time intervals, and the data codes for missing data and limits of detection are properly used. During the course of the project, there were 5,552 preliminary and 6,579 publication-quality data files submitted to the field data repository, including data revisions (e.g., Davis et al., 2018; Pal, 2019; Pal et al., 2020b). Another major function of the SSD-AC group was to generate merged products, which combined all in situ airborne measurements onto common time bases (see Section 3). Preliminary data typically went through multiple revisions. The publication-quality data is nominally submitted within six months of the end of each field campaign, though some data were subsequently revised (e.g., due to improved calibration and/or processing methods). The publication-quality data were released to the public and transferred to the ORNL DAAC for long-term preservation and public distribution. The field data repository will remain open to accept future data updates.

\subsection{Data Management and Publication at the ORNL DAAC}

The ORNL DAAC is one of 12 NASA Earth Observing System Data and Information System data centers, which provides open access to data from NASA's Earth Science Missions. The ORNL DAAC is the archive of record for the final ACT-America data products. Upon receipt of the ACT-America data, the ORNL DAAC evaluated the data for completeness and structure, created Climate and Forecasting (CF, https:// cfconventions.org) compliant netCDF (Network Common Data Form) files from the ICARTT source data, and archived and distributed files in both formats. In addition to being more broadly standards-compliant, self-describing, and consistent with interoperability best practices (see https://daac.ornl.gov/datamanagement), providing these netCDF files allow data users to take advantage of the numerous tools and opensource libraries that have been developed for netCDF data. These tools include the Thematic Real-time Environmental Distributed Data Services (THREDDS; https://daac.ornl.gov/cgi-bin/service_dataset_lister. pl?svc_id=4), which provides access and subsetting capabilities for netCDF data via programmatic and graphical interfaces.

ACT-America used an ICARTT-style file naming convention for all observational data products following the pattern: ACTAMERICA-instrument_platformID_YYYYMMDD_R\#_L\#.ext, where instrument is one of the instrument names listed in Table 1, platformID = "B200” or “C130', "merge”, or "Ground-"+ ground site name. YYYYMMDD = flight date in UTC time, $\mathrm{R} \#=$ revision number (higher number indicates a more recent revision), $\mathrm{L} \#=$ optional launch number (some B-200 flights had more than one sortie or launch on a single day), ext = file extension with either “.nc”/“.nc4” for NetCDF or “.ict' for ICARTT. For example, ACTAMERICA-Ozone_B200_20160726_R1_L2.nc is the netCDF file that contains the revision 1 of measurements made by the ozone instrument onboard the B-200 aircraft during its second launch on July 26, 2016.

Data files were grouped into a number of data products for publication at the ORNL DAAC, with each data product typically containing measurements from one instrument or a set of related instruments at a specific processing level (e.g., original or processed data set). The ORNL DAAC also prepared comprehensive NASA-compliant metadata and a detailed user guide to accompany each ACT-America data product. Each user guide includes the following information: Data citation, overview and description, spatial and temporal coverage and resolution, number of data files, file formats and standards, file naming conventions, data dictionary including all measured parameters, units, and description, data application and derivation, quality assessment and uncertainty information, detailed data acquisition and methods section, data access instructions, and references.

Upon publication at the ORNL DAAC, a formal citation, including the authors, title, and date of publication, and a unique Digital Object Identifier (DOI) was issued for each data product. The data citation and DOI provide a convenient and traceable identity for each specific data set that can be cited in the scholarly literature and linked to subsequent research efforts and products. In order to increase the visibility and maximize the scientific impact of NASA data products, the ORNL DAAC provides searchable metadata to 
a variety of relevant data catalogs, advertises the data online through email, news, and the DAAC website, and provides user support services.

Throughout the ACT-America project, data files were revised, recalibrated, and updated, as necessary. Close communication, and automated monitoring of data availability, were essential for keeping the LaRC data repository and the holdings at ORNL DAAC in sync. The ORNL DAAC data publication system captures the revision history of all published data sets and has the capability of notifying the users about the changes occurred in each revision. The data files in each revision are also preserved in the data system so users can always access data of a particular revision.

\section{Merged Airborne In Situ Data Products}

The airborne measurements from the ACT-America campaign were recorded on different native sampling time intervals ranging from milliseconds (e.g., $10 \mathrm{~Hz}$ for MFLL measurements) to multiple seconds (e.g., 5s temporal resolution for GHG measurements, Campbell et al., 2020). Additionally, instrument teams are responsible for reporting only their own data, without any of the navigational or meteorological parameters essential to its interpretation. Merging these various data files to a common standard sampling interval brings coherence to the data, creates geolocated data products, and makes it much easier for the data users to perform holistic analysis of the ACT-America data products. The ACT-America merged data products are generated at 1-s, 5-s, 60-s, and time intervals corresponding to flask sample fill times.

Merged data files in ICARTT format were prepared by the LaRC through a weighted average based on the overlap between the measurement and merge time intervals as described in Chen et al. (2018). The merge files are updated to reflect revisions of any observational data sets. For each individual RF, four key in situ observations collected by multiple instruments were merged: (a) navigational data, (b) GHG and trace gas mole fractions, (c) meteorological variables, and (d) flask samples. For the B-200, which needed refueling to cover long flight distances, the first and second sorties (L1 and L2, respectively) were also merged into a single file. In contrast, the C-130 endurance was long enough so that such sortie-merging was not required.

During the conversion of the merged data products from the ICARTT format to the netCDF format at the ORNL DAAC, the flight metadata flags (Davis et al., 2018) were added. The flight metadata flags provide information such as the type of aircraft maneuver underway (e.g., profile vs. level leg), whether or not the data are within the ABL, and the location of the data with respect to its synoptic environment (cold sector vs. warm sector of a mid-latitude weather system). These flags enable users to readily partition the data for analyses. In the future, we will add surface influence functions that use an atmospheric transport reanalysis to provide a quantitative connection between the airborne data and regions upwind whose fluxes impact those airborne observations. The file header of an example C-130 5-s merged file (version 1.2) (Davis et al., 2018) with all meteorological variables, trace gases, navigations, and flight metadata flags can be found in Table S2.

\section{Modeling Data Products and Management}

ACT-America brings together flux and transport models to generate simulated $\mathrm{CO}_{2}$ and $\mathrm{CH}_{4}$ mole fractions complementary to mission observations (Davis et al., 2021; Feng et al., 2019a) and inverse modeling systems needed to infer regional carbon fluxes using atmospheric carbon observations. The ACT-America regional inversion and ensemble modeling system (Barkley et al., 2019b; Butler et al., 2020; Diaz et al., 2018, 2019; Feng et al., 2019a, 2019b; Lauvaux et al., 2012) is the centerpiece of the ACT-America analysis system. Table $\mathrm{S} 3$ lists the major elements (e.g., transport, influence function, $\mathrm{CO}_{2}$ fluxes and boundary conditions, and $\mathrm{CH}_{4}$ and ethane fluxes) of the ACT-America reference simulations for all five seasonal campaigns. Table S4 lists the major elements of the ACT-America ensemble modeling system, including its three ensemble suites (i.e., transport, biogenic fluxes, and boundary conditions) and associated members. The ACT-America ensemble modeling system is important to quantify component-specific uncertainties (Feng et al., 2019a; Feng et al., 2019b; Feng et al., 2021). 
The goal of model data management for ACT-America is to facilitate the use of model data within the ACT-America science team. To achieve this goal, we followed lessons learned (Wei et al., 2014) from past research projects, i.e., the Multi-scale Synthesis and Terrestrial Model Intercomparison project (MsTMIP) (Huntzinger et al., 2013), to apply management practices for ACT-America model data products. Specifically, we ensured appropriate resources for model data planning, preparation, and management; established close collaboration between data experts and science researchers; produced model data and metadata in proper formats and standards; provided detailed data documentation, including the model data provenance; and provided an on-demand approach to distributing data.

The CF-compatible netCDF format was chosen for ACT-America model data products to increase usability and interoperability. The THREDDS data server allows data to be accessed through standard Web API (i.e., Open-source Project for a Network Data Access Protocol; OPeNDAP) in an on-demand manner. Users can choose to subset and access data in a region or temporal range of interest, instead of downloading the entire data files.

For model data, besides the fundamental characteristics (e.g., spatial extent, temporal extent, and variable names), one additional key metadata is their provenance, including the version of the transport model used, boundary conditions, and prior fluxes used in a particular simulation, and major model parameters. The data management team at the ORNL DAAC worked with the modeling scientists to document such provenance metadata for each simulation output.

\section{Applications of ACT-America Data}

The airborne measurements of atmospheric carbon dioxide, methane, trace gases, and meteorological properties alongside the continuous tower-based GHGs measurements over the Central and Eastern United States provide a valuable asset to improve the accuracy and precision of regional inverse flux estimates of GHGs. This asset has a wide range of applications, including but not limited to, quantifying and reducing uncertainties in simulated atmospheric transport of GHGs and in priori $\mathrm{CH}_{4}$ and $\mathrm{CO}_{2}$ flux estimates, especially $\mathrm{CH}_{4}$ emissions and biogenic $\mathrm{CO}_{2}$ fluxes; and evaluating the ability of the OCO-2 to observe spatial variations in tropospheric $\mathrm{CO}_{2}$ (Davis et al., 2021). Here, we highlight a specific case of frontal contrasts of GHGs and a summary of broader science applications using data products generated from the ACT-America project.

\subsection{Sample Data Analyses From a Frontal Flight}

The ACT-America team is analyzing how GHG distributions change vertically and horizontally across frontal boundaries (e.g., Pal et al., 2020a), and is comparing these observations to numerical simulations (Gerken et al., 2021; Samaddar et al., 2021). The 20 June 2019 RF described in Section 1.1 is an excellent illustration of the information available in one such flight.

As shown in Figure 3, the measurements show that $\mathrm{CO}_{2}$ frontal contrast (warm sector average minus cold sector average) in the ABL was 2.5 ppm, lower than the mid-to late-summer 2016 fronts (Pal et al., 2020a), perhaps due to stronger net photosynthesis in the Gulf in June as compared to July and August. This flight also captured the impact of late spring flooding which significantly delayed planting in the upper Midwest and suppressed net uptake of $\mathrm{CO}_{2}$ (Yin et al., 2020), further minimizing the cross-frontal contrast in $\mathrm{CO}_{2}$. An elevated $\mathrm{CO}_{2}$ band (416 ppm) was found at the frontal boundary, similar to results from the summer-2016 campaign (Figure 3a). This phenomenon appears closely tied to biological $\mathrm{CO}_{2}$ fluxes (Samaddar et al., 2021), perhaps particularly respiratory fluxes ( $\mathrm{Hu}$ et al., 2021). $\mathrm{CO}$ and $\mathrm{CH}_{4}$ mole fractions were higher in the cold sector than in the warm sector (Figures $3 \mathrm{~d}$ and 3e), likely indicative of large $\mathrm{CH}_{4}$ emissions from animal agriculture in the upper Midwest and perhaps larger upwind anthropogenic CO sources in

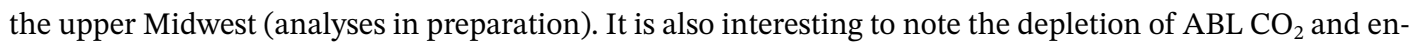
hancement in $\mathrm{ABL} \mathrm{CH} \mathrm{CH}_{4}$ across the Gulf states in comparison to the mole fractions in the Gulf of Mexico, indicative of the net uptake of $\mathrm{CO}_{2}$ and release of $\mathrm{CH}_{4}$ by coastal ecosystems. Finally, high $\mathrm{N}_{2} \mathrm{O}$ mole fractions in the cold sector were used to quantify emissions from upper Midwestern agriculture (Eckl et al., 2021). 

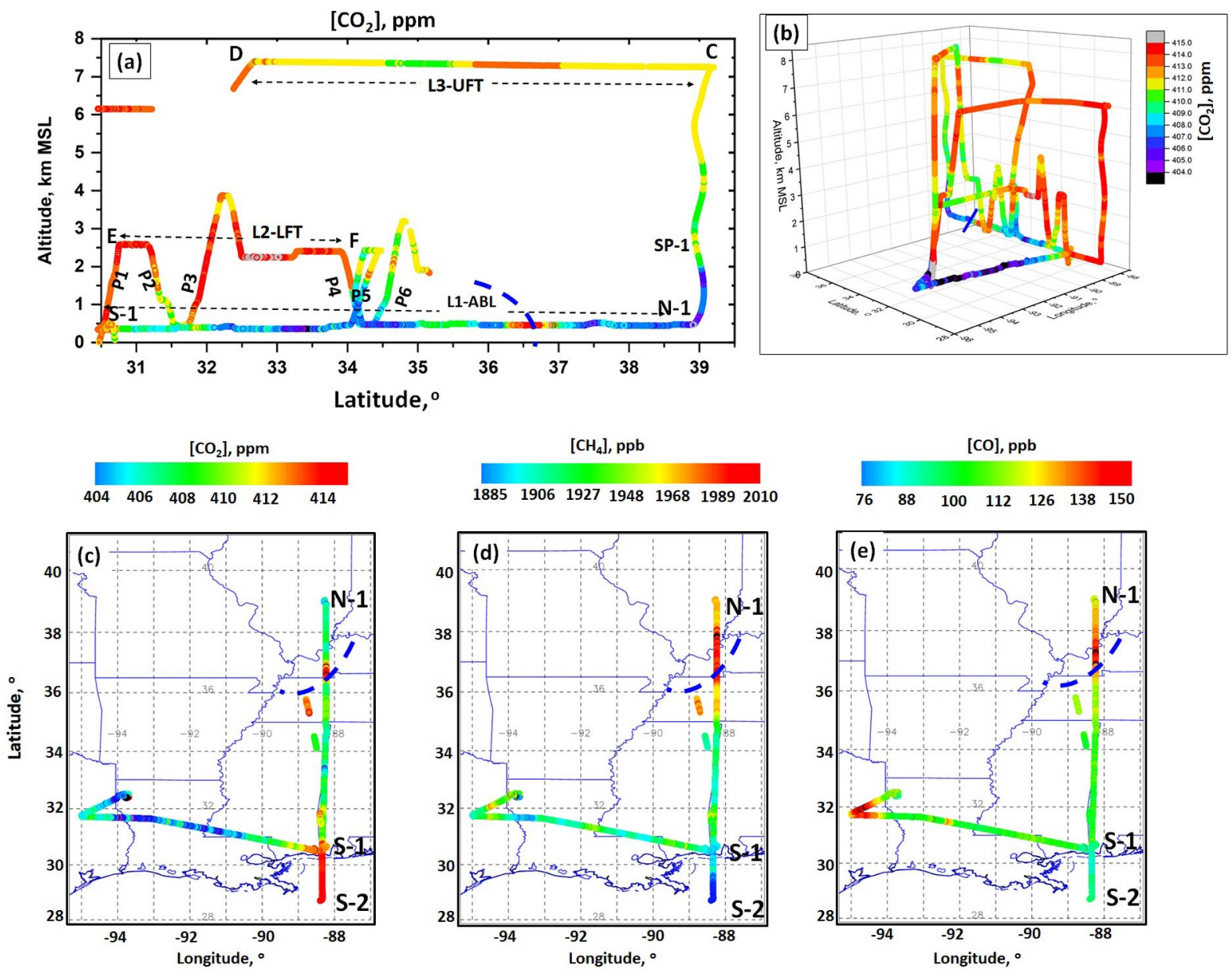

Figure 3. (a) Latitude-height cross-section of $\left[\mathrm{CO}_{2}\right]$ distributions along the tracks from point $\mathrm{N} 1$ to $\mathrm{S} 1$ shown in Figure $1 \mathrm{~h}$. L1, $\mathrm{L} 2$, and $\mathrm{L} 3 \mathrm{represent}$ level leg flights in the ABL, LFT and UFT, respectively; L1, L2, and L3 represent level leg flights in the ABL, LFT and UFT, respectively; P1, P2, P3 etc. denote en route vertical profiles and SP stands for spiral profile. (b) Three-dimensional overview of the $\mathrm{CO}_{2}$ distribution during the entire $\mathrm{RF}$. Spatial variability of $\left[\mathrm{CO}_{2}\right]$ (panel c) $\left[\mathrm{CH}_{4}\right]$ (d), and [CO] (e) in the ABL. In panels (c), (d), and (e), N1, S1, and S2 stand for northern most and two southern most points of the north-to-south flight leg. The approximate cold front location near the flight track is marked with a blue dashed line in all plots.

\subsection{Broader Applications of ACT-America Data}

Many additional studies have leveraged ACT-America measurements to improve our understanding and modeling of regional flux estimates of GHGs. For example, in Barkley et al. (2019a), $\mathrm{CH}_{4}$ and $\mathrm{C}_{2} \mathrm{H}_{6}$ observations (Davis, et al., 2018; DiGangi et al., 2018; Weibring et al., 2020) from the ACT-America campaigns were used to adjust oil/gas and animal agriculture emissions across the southcentral U.S. such that modeled $\mathrm{CH}_{4}$ and $\mathrm{C}_{2} \mathrm{H}_{6}$ enhancements match the observed plume. Successful modeling from this study raises the possibility of using trace gas measurements along frontal crossings to solve for emissions in other large regions of the United States. Baier et al. (2020) analyzed the multispecies measurements in flasks (Sweeney et al., 2015) sampled during the wintertime ACT-America campaign for background characterization and source apportionment of regional anthropogenic $\mathrm{CO}_{2}$ and $\mathrm{CH}_{4}$ fluxes. In the winter, fossil fuel influence was broadly observed throughout the entire observational domain. Feng et al. (2021) documented biases in biological models of summertime $\mathrm{CO}_{2}$ fluxes and compared inferences from the ACT-America flight data to NOAA tall tower and AmeriFlux flux towers.

Rigorous investigation of atmospheric GHG modeling systems is also underway. ACT-America airborne data are being used to evaluate OCO-2 Model Intercomparison Project (MIP) estimated $\mathrm{CO}_{2}$ fluxes. Gaudet et al. (2020), for example, evaluated the skill of 10 global $\mathrm{CO}_{2}$ inversion models from the OCO-2 MIP using 148 airborne vertical profiles of $\mathrm{CO}_{2}$ for frontal cases from the ACT-America Summer 2016 campaign. 
High-resolution models (Hu et al., 2021; Samaddar et al., 2021) of the elevated $\mathrm{CO}_{2}$ band observed along the frontal boundary shown in Pal et al. (2020a) have been evaluated using the ACT-America airborne data, as has a newly developed global $\mathrm{CO}_{2}$ transport model (Zheng et al., 2020). As noted previously, OCO-2 XCO variability at local to synoptic scales has been evaluated using ACT-America lidar and in situ observations (Bell et al., 2020).

Davis et al. (2021) provides a broad discussion of the scientific design of the mission and the applications of ACT-America data products.

\section{Accessibility of the ACT-America Data}

NASA promotes the full and open sharing of the Earth Science data with the research and applications communities, private industry, academia, and the general public (details at https:/earthdata.nasa.gov/ earth-observation-data/data-use-policy). Final data from ACT-America are available for free and open to the public from the ORNL DAAC, which is a CoreTrustSeal Certified Repository (https://www.coretrustseal.org/) and adheres to the Findability, Accessibility, Interoperability, and Reusability (FAIR) data principles (Wilkinson et al., 2016). Intermediate ACT-America data are currently available from NASA LaRC and PSU DataCommons (see Acknowledgments for details). A free NASA Earthdata Login account (https://urs. earthdata.nasa.gov) is required to access the ACT-America data from the ORNL DAAC. By establishing an account, users can be notified of changes or updates to the data. To better support the carbon cycle modeling research, ACT-America airborne and tower GHG observations are also integrated into the NOAA/ GML Observation Package (ObsPack) data products (Masarie et al., 2014). ObsPack brings together direct atmospheric greenhouse gas measurements derived from one or more national or university laboratories.

The Airborne Data Visualizer (ORNL DAAC, 2020) was developed to enhance the understanding and accessibility of the data collected for the ACT-America mission. It runs on a server maintained by the ORNL DAAC and takes advantage of the rich metadata packaged with the instrument measurements in the netCDF files to create an informative interface for exploration of the data.

The citations and DOIs are provided on the landing page and the User Guide of each final ACT-America data product published at the ORNL DAAC. To acknowledge the science teams who have created and shared data products, users should include a bibliographic citation to any data products used in publications. Proper citations, including the authors, title, publisher, and DOI, will help others find and re-use the data and also establish methods to track the impact of the ACT-America mission.

\section{Summary}

The ACT-America study is a multi-year effort to better understand and quantify sources and sinks of major greenhouse gases. ACT-America provides a unique and valuable asset of high-quality airborne measurements of atmospheric $\mathrm{CO}_{2}, \mathrm{CH}_{4}$, trace gases, and meteorological properties over the Central and Eastern US, along with tower-based measurements and modeled atmospheric greenhouse gases mole fractions and regional carbon fluxes. Through all five seasonal campaigns, a total of $121 \mathrm{RFs}$, more than $1,140 \mathrm{~h}$ of observations, 570 level legs, and 1,363 vertical profiles were conducted using the two aircraft, i.e., C-130 and B-200. ACT-America data products, including the merged airborne in situ data, provide a valuable asset to improve the accuracy and precision of regional inverse flux estimates of GHGs and beyond. A specific case of frontal contrasts of GHGs and a summary of broader science applications using data products generated from the ACT-America project are highlighted. A full catalog of known ACT-America publications can be found at the ORNL DAAC ACT-America website (https://actamerica.ornl.gov/publications.shtml). Better estimates of greenhouse gas transport, sources, and sinks, enabled by the detailed data collected by ACT-America, will help to reduce uncertainty in terrestrial carbon cycle models at regional to continental scales and to monitor regional carbon fluxes to support climate-change mitigation efforts. 


\section{Data Availability Statement}

The latest version of majority ACT-America observational data has been published and is open and freely available from the ORNL DAAC (https://daac.ornl.gov/actamerica). Some observational data (including the MFLL data and merged airborne in situ data) are still undergoing minor revisions. These intermediate revisions can currently be accessed from the NASA LaRC website (https://www-air.larc.nasa.gov/missions/ACT-America/), which will remain active until all final versions of ACT-America observational data are published by the ORNL DAAC and open and freely available from https://daac.ornl.gov/actamerica. The ACT-America model results are currently available from PSU DataCommons (reference simulations: https://doi.org/10.26208/7a4p-q224; ensemble simulations: https://doi.org/10.26208/z864-qk73). Selected model data, including the Carnegie-Ames-Stanford Approach (CASA) model ensemble biogenic fluxes, influence functions, and the reference simulations, have been or are being published at the ORNL DAAC and are or will be open and freely available from https://daac.ornl.gov/actamerica. ACT-America airborne and tower GHG observations are also integrated into the NOAA/GML ObsPack data products: https://www.esrl. noaa.gov/gmd/ccgg/obspack/.

\section{Acknowledgments}

The ACT-America project is a National Aeronautics and Space Administration (NASA) Earth Venture Suborbital 2 project funded by NASA's Earth Science Division. The ORNL DAAC is sponsored by NASA under Interagency Agreement 80GSFC19T0039. ORNL participation in ACT-America was funded by NASA under interagency agreement NNL15AA10I (Wei, Shreshta, Boyer). Other co-authors were supported by the following NASA grants: NNX15AG76 G to Penn State (Davis); NNX15AJ06 G (Baier, Sweeney) and NNX15AW47 G (Fried) to University of Colorado-Boulder; NNX16AN17 G to Clark University (Williams); NNL15AQ00 B to Exelis (Dobler); 80NSSC19K0730 to Texas Tech and a Texas Tech University start up research grant $(\mathrm{Pal})$; and NNX15AI97 G (O'Dell) to Colorado State University.

Complementary support for tower-based measurements was provided by NASA grant NNX14AJ17 G and NIST grant 70NANB15H336. NASA co-authors were supported by NASA Science Mission Directorate funding awarded in response to the Earth Venture Suborbital-2 Announcement of Opportunity NNH13ZDA001N-EVS2. Roiger was supported by DLR VO-R via the young investigator research group "Greenhouse Gases." T. Lauvaux was supported by the French research program Make Our Planet Great Again (project CIUDAD).

The authors acknowledge NASA's Earth System Science Pathfinder Program Office, NASA's Airborne Sciences Program, NASA's Atmospheric Science Data Center, as well as the administrative and flight forecasting support from PSU's Department of Meteorology and Atmospheric Sciences.

\section{References}

Aknan, A., Chen, G., Crawford, J., \& Williams, E. (2013). ICARTT file format standards V1.1, NASA. https://cdn.earthdata.nasa.gov/conduit/upload/499/ESDS-RFC-019-v1.1_0.pdf

Andrews, A. E., Kofler, J. D., Trudeau, M. E., Williams, J. C., Neff, D. H., Masarie, K. A., et al. (2014). CO2, CO, and CH4 measurements from tall towers in the NOAA earth system research laboratory's global greenhouse gas reference network: Instrumentation, uncertainty analysis, and recommendations for future high-accuracy greenhouse gas monitoring efforts. Atmospheric Measurement Techniques, 7, 647-687. https://doi.org/10.5194/amt-7-647-2014

Baier, B. C., Sweeney, C., Choi, Y., Davis, K. J., DiGangi, J. P., Feng, S., et al. (2020). Multispecies assessment of factors influencing regional $\mathrm{CO} 2$ and $\mathrm{CH} 4$ enhancements during the winter 2017 ACT-America campaign. Journal of Geophysical Research: Atmospheres, 125, e2019JD031339. https://doi.org/10.1029/2019JD031339

Baker, D. F., Bösch, H., Doney, S. C., O'Brien, D., \& Schimel, D. S. (2010). Carbon source/sink information provided by column CO2 measurements from the orbiting carbon observatory. Atmospheric Chemistry and Physics, 10, 4145-4165. https://doi.org/10.5194/ acp-10-4145-2010

Barkley, Z. R., Davis, K. J., Feng, S., Balashov, N., Fried, A., DiGangi, J., et al. (2019a). Forward modeling and optimization of methane emissions in the South Central United States using aircraft transects across frontal boundaries. Geophysical Research Letters, 46, 1356413573. https://doi.org/10.1029/2019GL084495

Barkley, Z. R., Lauvaux, T., Davis, K. J., Deng, A., Fried, A., Weibring, P., et al. (2019b). Estimating methane emissions from underground coal and natural gas production in southwestern Pennsylvania. Geophysical Research Letters, 46, 4531-4540. https://doi. org/10.1029/2019GL082131

Bell, E., O'Dell, C. W., Davis, K. J., Campbell, J., Browell, E., Scott Denning, A., et al. (2020). Evaluation of OCO-2 X variability at local and synoptic scales using lidar and in situ observations from the ACT-America campaigns. Journal of Geophysical Research - D: Atmospheres, 125, e2019JD031400. https://doi.org/10.1029/2019JD031400

Butler, M. P., Lauvaux, T., Liu, J., Bowman, K. W., Davis, K. J., \& Davis, K. J. (2020). Atmospheric simulations of total column CO2 mole fractions from global to mesoscale within the carbon monitoring system flux inversion framework. Atmosphere, $11,787$. https://doi.org/10.3390/atmos11080787

Campbell, J. F., Lin, B., Dobler, J., Pal, S., Davis, K., Obland, M. D., et al. (2020). Field evaluation of column CO2 retrievals from intensity-modulated continuous-wave differential absorption lidar measurements during the ACT-America campaign. Earth and Space Science, 7, e2019EA000847. https://doi.org/10.1029/2019EA000847

Chen, G., Kusterer, J. M., Early, A. B., \& Beach, A. (2018). TAD: Toolsets for airborne data. v1.3. Retrieved from https://tad.larc.nasa.gov/ media/TAD-Documentation.pdf

Chen, H. W., Zhang, L. N., Zhang, F., Davis, K. J., Lauvaux, T., Pal, S., et al. (2019). Evaluation of regional CO2 mole fractions in the ECMWF CAMS real-time atmospheric analysis and NOAA carbontracker near-real-time reanalysis with airborne observations from ACT-America field campaigns. Journal of Geophysical Research - D: Atmospheres, 124, 8119-8133. https://doi.org/10.1029/2018JD029992

Conley, S. A., Faloona, I. C., Lenschow, D. H., Karion, A., \& Sweeney, C. (2014). A low-cost system for measuring horizontal winds from single-engine aircraft. Journal of Atmospheric and Oceanic Technology, 31, 1312-1320. https://doi.org/10.1175/JTECH-D-13-00143.1

Davis, K. J., Browell, E. V., Feng, S., Lauvaux, T., Obland, M., Pal, S., et al. (2021). Design and implementation of the Atmospheric Carbon and Transport (ACT) - America earth venture suborbital mission. Bulletin of the American Meteorological Society, in review. https:// www.essoar.org/doi/10.1002/essoar.10505721.1

Davis, K. J., Obland, M. D., Lin, B., Lauvaux, T., O'Dell, C., Meadows, B., et al. (2018). ACT-America: L3 merged in situ atmospheric trace gases and flask data, USA. ORNL DAAC. https://doi.org/10.3334/ORNLDAAC/1593

Díaz-Isaac, L. I., Lauvaux, T., Bocquet, M., \& Davis, K. J. (2019). Calibration of a multi-physics ensemble for estimating the uncertainty of a greenhouse gas atmospheric transport model. Atmospheric Chemistry and Physics, 19, 5695-5718. https://doi.org/10.5194/ acp-19-5695-2019

Díaz-Isaac, L. I., Lauvaux, T., \& Davis, K. J. (2018). Impact of physical parameterizations and initial conditions on simulated atmospheric transport and CO2 mole fractions in the US Midwest. Atmospheric Chemistry and Physics, 18, 14813-14835. https://doi.org/10.5194/ acp-18-14813-2018

DiGangi, J. P., Choi, Y., Nowak, J. B., Halliday, H. S., Yang, M. M., Baier, B. C., \& Sweeney, C. (2018). ACT-America: L2 in situ atmospheric $\mathrm{CO} 2 \mathrm{CO}, \mathrm{CH} 4$, and $\mathrm{O} 3$ concentrations, USA. ORNL DAAC. https://doi.org/10.3334/ORNLDAAC/1556 
Dobler, J. T., Harrison, F. W., Browell, E. V., Lin, B., McGregor, D., Kooi, S., et al. (2013). Atmospheric CO2 column measurements with an airborne intensity-modulated continuous wave $157 \mu \mathrm{m}$ fiber laser lidar. Applied Optics, 52, 2874-2892. https://doi.org/10.1364/ AO. 52.002874

Eaton, B., Gregory, J., Drach, B., Taylor, K., Hankin, S., Blower, et al. (2017). NetCDF climate and forecast (CF) metadata conventions v1.7. 2017. Retrieved from http://cfconventions.org/Data/cf-conventions/cf-conventions-1.7/cf-conventions.html

Eckl, M., Roiger, A., Kostinek, J., Fiehn, A., Huntrieser, H., Knote, C., et al. (2021). Quantifying nitrous oxide emissions in the U.S. Midwest - A top-down study using high resolution airborne in situ observations. Geophysical Research Letters, 48, e2020GL091266. https://doi. org/10.1029/2020GL091266

Eldering, A., O'Dell, C. W., Wennberg, P. O., Crisp, D., Gunson, M. R., Viatte, C., et al. (2017). The orbiting carbon observatory-2: First 18 months of science data products. Atmospheric Measurement Technique, 10, 549-563. https://doi.org/10.5194/amt-10-549-2017

Feng, S., Lauvaux, T., Davis, K. J., Keller, K., Zhou, Y., Williams, C., et al. (2019a). Seasonal Characteristics of Model Uncertainties From biogenic fluxes, transport, and large-scale boundary inflow in atmospheric CO2 simulations over North America. Journal of Geophysical Research - D: Atmospheres, 124, 14325-14346. https://doi.org/10.1029/2019JD031165

Feng, S., Lauvaux, T., Keller, K., Davis, K. J., Rayner, P., Oda, T., \& Gurney, K. R. (2019b). A road map for improving the treatment of uncertainties in high-resolution regional carbon flux inverse estimates. Geophysical Research Letters, 46, 13461-13469. https://doi. org/10.1029/2019GL082987

Feng, S., Lauvaux, T., Williams, C. A., Davis, K. J., Zhou, Y., Baker, I., et al. (2021). Joint CO2 mole fraction and flux analysis confirms missing processes in CASA terrestrial carbon uptake over North America. Earth and Space Science Open Archive, in review. https://doi. org/10.1002/essoar.10505330.1

Gaudet, B. J., Davis, K. J., Pal, S., Jacobson, A. R., Schuh, A., Lauvaux, T., et al. (2021). Regional-scale, sector-specific evaluation of global $\mathrm{CO}_{2}$ inversion models using aircraft data from the ACT-America project. Journal of Geophysical Research: Atmospheres, 126(4). http:// dx.doi.org/10.1029/2020jd033623

Gerken, T., Feng, S., Klaus, K., Davis, K. J., Lauvaux, T., Jacobson, A. R., et al. (2021). Examing CO2 model observation residuals during ACT-America. Journal of Geophysical Research: Atmospheres, in review. https://doi.org/10.1002/essoar.10505673.1

Hu, L., Andrews, A. E., Thoning, K. W., Sweeney, C., Miller, J. B., Michalak, A. M., et al. (2019). Enhanced North American carbon uptake associated with El Niño. Science Advances, 5, eaaw0076. https://doi.org/10.1126/sciadv.aaw0076

Hu, X. M., Gourdji, S. M., Davis, K. J., Wang, Q., Zhang, Y., Xue, M., et al. (2021). Implementation of improved parameterization of terrestrial flux in WRF-VPRM improves the simulation of nighttime CO2 peaks and a daytime CO2 Band Ahead of a Cold front. Journal of Geophysical Research Atmospheres, 126, e2020JD034362. https://doi.org/10.1029/2020JD034362

Huntzinger, D. N., Schwalm, C., Michalak, A. M., Schaefer, K., King, A. W., Wei, Y., et al. (2013). The North American carbon program multi-scale synthesis and terrestrial model intercomparison project - Part 1: Overview and experimental design. Geoscientific Model Development, 6, 2121-2133. https://doi.org/10.5194/gmd-6-2121-2013

Jacobson, A. R., Schuldt, K. N., Miller, J. B., Oda, T., Tans, P., Andrews, A., et al. (2020). CarbonTracker CT2019. NOAA Earth System Research Laboratory, Global Monitoring Division. https://doi.org/10.25925/39M3-6069

Kostinek, J., Roiger, A., Davis, K. J., Sweeney, C., DiGangi, J. P., Choi, Y., et al. (2019). Adaptation and performance assessment of a quantum and interband cascade laser spectrometer for simultaneous airborne in situ observation of $\mathrm{CH} 4, \mathrm{C} 2 \mathrm{H} 6, \mathrm{CO} 2, \mathrm{CO}$ and $\mathrm{N} 2 \mathrm{O}$. Atmospheric Measurement Techniques, 12, 1767-1783. https://doi.org/10.5194/amt-12-1767-2019

Lauvaux, T., Schuh, A. E., Uliasz, M., Richardson, S., Miles, N., Andrews, A. E., et al. (2012). Constraining the CO2 budget of the corn belt: Exploring uncertainties from the assumptions in a mesoscale inverse system. Atmospheric Chemistry and Physics, 12, 337-354. https:// doi.org/10.5194/acp-12-337-2012

Lin, B., Campbell, J. F., Dobler, J., Browell, E. V., Kooi, S. A., Pal, S., et al. (2018). ACT-America: L2 remotely sensed column-average CO2 by airborne lidar, eastern USA. ORNL DAAC, USA. https://doi.org/10.3334/ORNLDAAC/1649

Lin, B., Ismail, S., Wallace Harrison, F., Browell, E. V., Nehrir, A. R., Dobler, J., et al. (2013). Modeling of intensity-modulated continuous-wave laser absorption spectrometer systems for atmospheric CO2 column measurements. Applied Optics, 52, 7062-7077. https:// doi.org/10.1364/AO.52.007062

Masarie, K. A., Peters, W., Jacobson, A. R., \& Tans, P. P. (2014). ObsPack: A framework for the preparation, delivery, and attribution of atmospheric greenhouse gas measurements. Earth System Science Data, 6, 375-384. https://doi.org/10.5194/essd-6-375-2014

McGill, M. J., Vaughan, M. A., Trepte, C. R., Hart, W. D., Hlavka, D. L., Winker, D. M., \& Kuehn, R. (2007). Airborne validation of spatial properties measured by the CALIPSO lidar. Journal of Geophysical Research, 112, D20201. https://doi.org/10.1029/2007JD008768

Miles, N. L., Richardson, S. J., Martins, D. K., Davis, K. J., \& Haupt, B. J. (2020). ACT-America: L1 raw, uncalibrated in-situ CO2, CO, and CH4 mole fractions from towers. ORNL DAAC, USA. https://doi.org/10.3334/ORNLDAAC/1798

Miles, N. L., Richardson, S. J., Martins, D. K., Davis, K. J., Lauvaux, T., Haupt, B. J., \& Miller, S. K. (2018). ACT-America: L2 in situ CO2, CO, and $\mathrm{CH} 4$ concentrations from towers, eastern USA. ORNL DAAC, USA. https://doi.org/10.3334/ORNLDAAC/1568

Nehrir, A. R., Hair, J. W., Ferrare, R. A., Hostetler, C. A., Kooi, S. A., Notari, A., et al. (2018). The high altitude lidar observatory (HALO): A multi-function lidar and technology testbed for airborne and space-based measurements of water vapor and methane. American Geophysical Union, Fall Meeting, abstract \#A31P-3155.

Obland, M. D., Nehrir, A., Antill, C., Campbell, J., Lin, B., Kooi, S., et al. (2015). Technology Advancement for Active Remote Sensing of Carbon Dioxide from Space Using the ASCENDS CarbonHawk Experiment Simulator (ACES), 11th International Workshop on Greenhouse Gas Measurements from Space, CA. 18.

ORNL, DAAC. (2020). ORNL DAAC airborne data visualizer. ORNL DAAC, USA. https://doi.org/10.3334/ORNLDAAC/1860

Pal, S. (2019). ACT-America: Profile-based planetary boundary layer heights, eastern USA. ORNL DAAC, USA. https://doi.org/10.3334/ ORNLDAAC/1706

Pal, S., \& Davis, K. J. (2021). ACT-America field campaign catalog. (https://actamerica.ornl.gov/campaigns.html) ORNL DAAC, USA. https://doi.org/10.3334/ORNLDAAC/1862

Pal, S., Davis, K. J., Lauvaux, T., Browell, E. V., Gaudet, B. J., Stauffer, D. R., et al. (2020a). Observations of greenhouse gas changes across summer frontal boundaries in the eastern United States. Journal of Geophysical Research: Atmospheres, 125, e2019JD030526. https:// doi.org/10.1029/2019JD030526

Pal, S., Davis, K. J., Pauly, R. M., McGill, M. J., Campbell, L. J., Hoffman, K., et al. (2020b). ACT-America: CPL-derived atmospheric boundary layer top height, eastern US, 2016-2018. ORNL DAAC, USA. https://doi.org/10.3334/ORNLDAAC/1825

Peters, W., Jacobson, A. R., Sweeney, C., Andrews, A. E., Conway, T. J., Masarie, K., et al. (2007). An atmospheric perspective on North American carbon dioxide exchange: CarbonTracker. Proceedings of the National Academy of Sciences 104, 18925-18930. https://doi. org/10.1073/pnas.0708986104 
Samaddar, A., Feng, S., Lauvaux, T., Barkley, Z. R., Pal, S., \& Davis, K. J. (2021). Carbon dioxide distribution, origins, and transport along a frontal boundary during summer in mid-latitudes. Journal of Geophysical Research Atmospheres, 126. https://doi. org/10.1029/2020JD033118

Sweeney, C., Baier, B. C., Miller, J. B., Lang, P., Miller, B. R., Lehman, S., et al. (2018). ACT-America: L2 in situ atmospheric gas concentrations from flasks, USA. ORNL DAAC. https://doi.org/10.3334/ORNLDAAC/1575

Sweeney, C., Karion, A., Wolter, S., Newberger, T., Guenther, D., Higgs, J. A., et al. (2015). Seasonal climatology of CO2 across North America from aircraft measurements in the NOAA/ESRL Global Greenhouse Gas Reference Network. Journal of Geophysical Research: Atmospheres, 120, 5155-5190. https://doi.org/10.1002/2014JD022591

Turnbull, J. C., Miller, J. B., Lehman, S. J., Hurst, D., Peters, W., Tans, P. P., et al. (2009). Spatial distribution of $\Delta 14 C O 2$ across Eurasia: Measurements from the TROICA-8 expedition. Atmospheric Chemistry and Physics, 9, 175-187. https://doi.org/10.5194/acp-9-175-2009

Uliasz, M. (1994). Lagrangian particle dispersion modeling in mesoscale applications. In P. Zanetti (Ed.), Environmental modeling II (pp. 71-102). Computational Mechanics Publications.

Wei, Y., Liu, S., Huntzinger, D. N., Michalak, A. M., Viovy, N., Post, W. M., et al. (2014). The North American carbon program multi-scale synthesis and terrestrial model intercomparison project - Part 2: Environmental driver data. Geoscientific Model Development, 7, 28752893. https://doi.org/10.5194/gmd-7-2875-2014

Weibring, P., Richter, D., Walega, J. G., Fried, A., DiGangi, J., Halliday, H., et al. (2020). Autonomous airborne mid-infrared spectrometer for high-precision measurements of ethane during the NASA ACT-America studies. Atmosperic Measurement Techniques, 13, 6095, 6112. https://doi.org/10.5194/amt-13-6095-2020

Wilkinson, M. D., Dumontier, M., Aalbersberg, I. J., Appleton, G., Axton, M., Baak, A., et al. (2016). The FAIR Guiding Principles for scientific data management and stewardship. Science Data 3, 160018. https://doi.org/10.1038/sdata.2016.18

Yin, Y., Byrne, B., Liu, J., Wennberg, P., Davis, K. J., Magney, T., et al. (2020). Cropland carbon uptake delayed and reduced by 2019 Midwest floods. AGU Advances, 1, e2019AV000140.

Zheng, T., Feng, S., Davis, K. J., Pal, S., \& Morguí, J. A. (2020). Development and evaluation of $\mathrm{CO}_{2}$ transport in MPAS-A v6.3. Geoscientific Model Development, 14(5), 3037-3066. http://dx.doi.org/10.5194/gmd-14-3037-2021

Zhou, Y., Williams, C. A., Lauvaux, T., Feng, S., Baker, I., Wei, Y., et al. (2019). ACT-America: Gridded ensembles of surface biogenic carbon fluxes for north America and the conterminous United States, 2003-2019. ORNL DAAC, USA. https://doi.org/10.3334/ORNLDAAC/1675

\section{References From the Supporting Information}

Baker, D. F., Bösch, H., Doney, S. C., O'Brien, D., \& Schimel, D. S. (2010). Carbon source/sink information provided by column CO2 measurements from the Orbiting Carbon Observatory. Atmospheric Chemistry and Physics, 10, 4145-4165. https://doi.org/10.5194/ acp-10-4145-2010

Baker, I. T., Prihodko, L., Denning, A. S., Goulden, M., Miller, S., \& da Rocha, H. R. (2008). Seasonal drought stress in the Amazon: Reconciling models and observations. Journal of Geophysical Research, 113. https://doi.org/10.1029/2007jg000644

Barkley, Z. R., Davis, K. J., Feng, S., Cui, Y. Y., Fried, A., Weibring, P., et al. (2021). Analysis of oil and gas ethane and methane emissions in the southcentral and Eastern United States using four seasons of continuous aircraft ethane measurements. Journal of Geophysical Research: Atmospheres, 126(10). https://doi.org/10.1029/2020jd034194

Barrick, J. D., Ritter, J. A., Watson, C. E., WynKoop, M. W., Quinn, J. K., \& Norfolk, D. R. (1996). Calibration of the NASA turbulent air motion measurement system, NASA Technical Paper 3610.

Basu, S., Miller, J. B., \& Lehman, S. (2016). Separation of biospheric and fossil fuel fluxes of CO2 by atmospheric inversion of CO2 and 14CO2 measurements: Observation System Simulations. Atmospheric Chemistry and Physics, 16, 5665-5683. https://doi.org/10.5194/ acp-16-5665-2016

Berner, J., Shutts, G. J., Leutbecher, M., \& Palmer, T. N., (2009). A spectral stochastic kinetic energy backscatter scheme and its impact on flow-dependent predictability in the ECMWF ensemble prediction system. Journal of the Atmospheric Sciences, 66, 603-626. https://doi. org/10.1175/2008JAS2677.1

Bloom, A. A., Bowman, K. W., Lee, M., Turner, A. J., Schroeder, R., Worden, J. R., et al. (2017). A global wetland methane emissions and uncertainty dataset for atmospheric chemical transport models (WetCHARTs version 1.0). Geoscientific Model Development, 10(6), 2141-2156. https://doi.org/10.5194/gmd-10-2141-2017

Bosilovich, M. G., Robertson, F. R., Takacs, L., Molod, A., \& Mocko, D. (2017). Atmospheric water balance and variability in the MERRA-2 reanalysis. Journal of Climate, 30, 1177-1196. https://doi.org/10.1175/JCLI-D-16-0338.1

Burton, S. P., Ferrare, R. A., Hostetler, C. A., Hair, J. W., Rogers, R. R., Obland, M. D., et al. (2012). Aerosol classification using airborne high spectral resolution lidar measurements - Methodology and examples. Atmospheric Measurement Techniques, 5, 73-98. https://doi. org/10.5194/amt-5-73-2012

Chen, F., \& Dudhia, J. (2001). Coupling an advanced land surface-Hydrology model with the penn state-NCAR MM5 Modeling system. Part I: Model implementation and sensitivity. Monthly Weather Review, 129(4), 569-585. https://doi. org/10.1175/1520-0493(2001)129<0569:CAALSH>2.0.CO;2

Cui, Y. Y., Jacobson, A. R., Feng, S., Wesloh, D., Gerken, T., Barkley, et al. (2021). Evaluation of inverse estimates of North American net ecosystem exchange of $\mathrm{CO} 2$ from different observing systems using ACT-America airborne observations. Journal of Geophysical Research - D: Atmospheres, In review. https://doi.org/10.1002/essoar.10505569.1

Davis, K. J., Gamage, N., Hagelberg, C., Lenschow, D. H., Kiemle, C., \& Sullivan, P. P. (2000). An objective method for determining atmospheric structure from airborne lidar observations. Journal of Atmospheric Oceanic Techniques, 17, 1455-1468. https://doi.org/10.1175/1 520-0426(2000)017<1455:AOMFDA>2.0.CO;2

Dlugokencky, E. J., Myers, R. C., Lang, P. M., Masarie, K. A., Crotwell, A. M., Thoning, K. W., et al. (2005). Conversion of NOAA atmospheric dry air CH4 mole fractions to a gravimetrically prepared standard scale. Journal of Geophysical Research, 110, D18306. https:// doi.org/10.1029/2005JD006035

Fisher, J. B., Sikka, M., Huntzinger, D. N., Schwalm, C. R., Liu, J., Wei, Y., et al. (2016). CMS: Modeled net ecosystem exchange at 3-hourly time steps, 2004-2010. ORNL DAAC, USA. https://doi.org/10.3334/ORNLDAAC/1315

Haering, E. A. (1990). Airdata calibration of a high-performance aircraft for measuring atmospheric wind profiles. NASA TM-101714.

Hair, J. W., Hostetler, C. A., Cook, A. L., Harper, D. B., Ferrare, R. A., Mack, T. L., et al. (2008). Airborne High Spectral Resolution Lidar for profiling aerosol optical properties. Applied Optics, 47, 6734-6752. https://doi.org/10.1364/AO.47.006734 
Hall, B. D., Dutton, G. S., \& Elkins, J. W. (2007). The NOAA nitrous oxide standards scale for atmospheric observations. Journal of Geophysical Research, vol 112, D09035. https://doi.org/10.1029/2006JD007954

Hayes, D. J., McGuire, A. D., Kicklighter, D. W., Gurney, K. R., Burnside, T. J., \& Melillo, J. M. (2011). Is the northern high-latitude landbased CO2 sink weakening? Global Biogeochemical Cycles, 25, GB3018. https://doi.org/10.1029/2010GB003813

Hersbach, H., Bell, B., Berrisford, P., Hirahara, S., Horányi, A., Muñoz-Sabater, J., et al. (2020). The ERA5 global reanalysis. Quarterly Journal of the Royal Meteorological Society, 146(730), 1999-2049. https://doi.org/10.1002/qj.3803

Hlavka, D. L., Yorks, J. E., Young, S. A., Vaughan, M. A., Kuehn, R. E., McGill, M. J., \& Rodier, S. D. (2012). Airborne validation of cirrus cloud properties derived from CALIPSO lidar measurements: Optical properties. Journal of Geophysical Research, 117, D09207. https:// doi.org/10.1029/2011JD017053

Hong, S., Noh, Y., \& Dudhia, J. (2006). A new vertical diffusion package with an explicit treatment of entrainment processes. Monthly Weather Review, 134, 2318-2341. https://doi.org/10.1175/MWR3199.1

Huang, S., Arain, M. A., Arora, V. K., Yuan, F., Brodeur, J., \& Peichl, M. (2011). Analysis of nitrogen controls on carbon and water exchanges in a conifer forest using the CLASS-CTEM N+ model. Ecological Modelling, 222, 3743-3760.

Huntzinger, D. N., Schwalm, C., Michalak, A. M., Schaefer, K., King, A. W., Wei, Y., et al. (2013). The North American carbon program multi-scale synthesis and terrestrial model intercomparison project - Part 1: Overview and experimental design. Geoscience Model Development, 6, 2121-2133. https://doi.org/10.5194/gmd-6-2121-2013

Ito, A. (2010). Changing ecophysiological processes and carbon budget in East Asian ecosystems under near-future changes in climate: Implications for long-term monitoring from a process-based model. Journal of Plant Research, 123, 577-588.

Jain, A. K. \& Yang, X. (2005). Modeling the effects of two different land cover change data sets on the carbon stocks of plants and soils in concert with CO2 and climate change. Global Biogeochemical Cycles, 19, GB2015. https://doi.org/10.1029/2004gb002349

Janjić, Z. I. (1994). The step-mountain eta coordinate model: Further developments of the convection, viscous sublayer, and turbulence closure schemes. Monthly Weather Review, 122, 927-945. https://doi.org/10.1175/1520-0493(1994)122<0927:TSMECM>2.0.CO;2

Janssens-Maenhout, G., Crippa, M., Guizzardi, D., Muntean, M., Schaaf, E., Dentener, F., et al. (2019). EDGAR v4.3.2 Global Atlas of the three major greenhouse gas emissions for the period 1970-2012. Earth System Science Data, 11(3), 959-1002. https://doi.org/10.5194/ essd-11-959-2019

Krinner, G., Viovy, N., de Noblet-Ducoudré, N., Ogé, J., Polcher, J., Friedlingstein, P., et al. (2005). A dynamic global vegetation model for studies of the coupled atmosphere-biosphere system. Global Biogeochemical Cycles, 19, GB1015. https://doi.org/10.1029/2003gb002199

Lei, H., Huang, M., Leung, L. R., Yang, D., Shi, X., Mao, J., et al. (2014). Sensitivity of global terrestrial gross primary production to hydrologic states simulated by the Community Land Model using two runoff parameterizations. Journal of Advances in Modeling Earth Systems, 6, 658-679. https://doi.org/10.1002/2013MS000252

Liu, J., Bowman, K. W., Lee, M., Henze, D. K., Bousserez, N., Brix, H., et al. (2014). Carbon monitoring system flux estimation and attribution: Impact of ACOS-GOSAT XCO2 sampling on the inference of terrestrial biospheric sources and sinks. Tellus B: Chemical and Physical Meteorology, 66(1). https://doi.org/10.3402/tellusb.v66.22486

Maasakkers, J. D., Jacob, D. J., Sulprizio, M. P., Turner, A. J., Weitz, M., Wirth, T., et al. (2016). Gridded National Inventory of U.S. Methane Emissions. Environmental Science \& Technology, 50(23), 13123-13133. https://doi.org/10.1021/acs.est.6b02878

Mao, J., Thornton, P. E., Shi, X., Zhao, M., \& Post, W. M. (2012). Remote sensing evaluation of CLM4 GPP for the period 2000-09*. Journal of Climate, 25(15), 5327-5342. https://doi.org/10.1175/jcli-d-11-00401.1

McGill, M., Hlavka, D., Hart, W., Scott, V. S., Spinhirne, J., \& Schmid, B. (2002). Cloud physics lidar: Instrument description and initial measurement results. Applied Optics, 41, 3725-3734. https://doi.org/10.1364/AO.41.003725

McGill, M. J., Hlavka, D. L., Hart, W., Welton, E. J., \& Campbell, J. R. (2003). Airborne lidar measurements of aerosol optical properties during SAFARI-2000. Journal of Geophysical Research, 108, 8493. https://doi.org/10.1029/2002DJ002370

McGill, M. J., Li, L., Hart, W. D., Heymsfield, G. M., Hlavka, D. L., Racette, P. E., et al. (2004). Combined lidar-radar remote sensing: Initial results from CRYSTAL-FACE. Journal of Geophysical Research, 109. https://doi.org/10.1029/2003JD004030

Miller, J. B., Mack, K. A., Dissly, R., White, J. W. C., Dlugokencky, E. J., \& Tans, P. P. (2002). Development of analytical methods and measurements of $13 \mathrm{C} / 12 \mathrm{C}$ in atmospheric $\mathrm{CH} 4$ from the NOAA Climate Monitoring and Diagnostics Laboratory Global Air Sampling Network. Journal of Geophysical Research, 107, D13. ACH-11. https://doi.org/10.1029/2001JD000630

Mostafa, M., Hutton, J., \& Reid, B. (2001). GPS/IMU products - the Applanix approach. Proceedings of 48th Photogrammetric Week, September 24-28, 2001, Stuttgart, Germany, pp63-83.

Nakanishi, M., \& Niino, H. (2006). An improved mellor-yamada level-3 model: Its numerical stability and application to a regional prediction of advection fog. Boundary-Layer Meteorology, 119(2), 397-407. https://doi.org/10.1007/s10546-005-9030-8

Nehrir, A. R., Kiemle, C., Lebsock, M. D., Kirchengast, G., Buehler, S. A., Löhnert, U., et al. (2017). Emerging technologies and synergies for airborne and space-based measurements of water vapor profiles. Surveys in Geophysics, 38, 1445-1482. https://doi.org/10.1007/ s10712-017-9448-9

Novelli, P. C., Elkins, J. W., \& Steele, L. P. (1991). Development and evaluation of a gravimetric reference scale for measurements of atmospheric carbon monoxide. Journal of Geophysical Research, 96, 13109-13121. https://doi.org/10.1029/91JD01108

Peng, C., Liu, J., Dang, Q., Apps, M. J., \& Jiang, H. (2002). TRIPLEX: A generic hybrid model for predicting forest growth and carbon and nitrogen dynamics. Ecological Modelling, 153(1/2), 109-130. https://doi.org/10.1016/s0304-3800(01)00505-1

Ricciuto, D. M., King, A. W., Dragoni, D., \& Post, W. M. (2011). Parameter and prediction uncertainty in an optimized terrestrial carbon cycle model: Effects of constraining variables and data record length. Journal of Geophysical Research, 116. https://doi. org/10.1029/2010JG001400

Richardson, S. J., Miles, N. L., Davis, K. J., Lauvaux, T., Martins, D. K., Turnbull, J. C., et al. (2017). Tower measurement network of in-situ CO2, CH4, and CO in support of the Indianapolis FLUX (INFLUX) Experiment. Elem Sci Anth, 5, 59. https://doi.org/10.1525/ elementa. 140

Scarino, A. J., Obland, M. D., Fast, J. D., Burton, S. P., Ferrare, R. A., Hostetler, C. A., et al. (2014). Comparison of mixed layer heights from airborne high spectral resolution lidar, ground-based measurements, and the WRF-Chem model during CalNex and CARES. Atmospheric Chemistry and Physics, 14, 5547-5560. https://doi.org/10.5194/acp-14-5547-2014

Schaefer, K., Collatz, G. J., Tans, P., Denning, A. S., Baker, I., Berry, et al. (2008). Combined Simple Biosphere/Carnegie-Ames-Stanford Approach terrestrial carbon cycle model. Journal of Geophysical Research, 113, G03034. https://doi.org/10.1029/2007jg000603

Schuh, A. E., Jacobson, A. R., Basu, S., Weir, B., Baker, D., Bowman, K., et al. (2019). Quantifying the impact of atmospheric transport uncertainty on CO2 surface flux estimates. Global Biogeochemical Cycles, 33, 484- 500. https://doi.org/10.1029/2018GB006086 


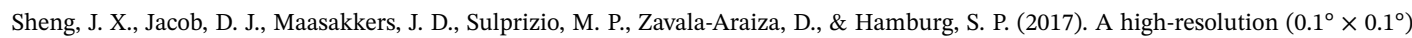
inventory of methane emissions from Canadian and Mexican oil and gas systems. Atmospheric Environment, 158, 211-215. https://doi. org/10.1016/j.atmosenv.2017.02.036

Shutts, G. J. (2005). A kinetic energy backscatter algorithm for use in ensemble prediction systems. Quarterly Journal of Royal Meteoreological Society, 131, 3079-3102. https://doi.org/10.1256/qj.04.106

Sitch, S., Smith, B., Prentice, C. I., Arneth, A., Bondeau, A., Cramer, et al. (2003). Evaluation of ecosystem dynamics, plant geography and terrestrial carbon cycling in the LPJ dynamic global vegetation model. Global Change Biology, 9(2), 161-185. http://doi. org/10.1046/j.1365-2486.2003.00569.x

Stickney, T. M., Shedlov, M. W., \& Thompson, D. I. (1990). Rosemount total temperature sensors. Technical Report D, 5755.

Sugimoto, N., \& Lee, C. H. (2006). Characteristics of dust aerosols inferred from lidar depolarization measurements at two wavelengths. Applied Optics, 45, 7468-7474. https://doi.org/10.1364/AO.45.007468

Thornton, P. E., Law, B. E., Gholz, H. L., Clark, K. L., Falge, E., Ellsworth, D. S., et al. (2002) Modeling and measuring the effects of disturbance history and climate on carbon and water budgets in evergreen needleleaf forests. Agricultural and Forest Meteorology, 113, 185-222.

Tian, H., Chen, G., Zhang, C., Liu, M., Sun, G., Chappelka, et al. (2012). Century-scale responses of ecosystem carbon storage and flux to multiple environmental changes in the southern United States. Ecosystems, 15, 674-694.

Trolier, M., White, J. W. C., Tans, P. P., Masarie, K. A., \& Gemery, P. A. (1996). Monitoring the isotopic composition of atmospheric CO2: Measurements from the NOAA Global Air Sampling Network. Journal of Geophysical Research, 101, 25897-25916. https://doi. org/10.1029/96JD02363

Turnbull, J. C., Lehman, S. J., Miller, J. B., Sparks, R. J., Southon, J. R., \& Tans, P. P. (2007). A new high precision14CO2 time series for North American continental air. Journal of Geophysical Research, 112, D11310. https://doi.org/10.1029/2006JD008184

Turner, A. J., Jacob, D. J., Wecht, K. J., Maasakkers, J. D., Lundgren, E., Andrews, A. E., et al. (2015). Estimating global and North American methane emissions with high spatial resolution using GOSAT satellite data. Atmospheric Chemistry and Physics, 15(12), 7049-7069. https://doi.org/10.5194/acp-15-7049-2015

Vaughn, B. H., Miller, J., Ferretti, D. F., \& White, J. W. C. (2004). Stable isotope measurements of atmospheric CO2 and CH4. Handbook of stable isotope analytical techniques. Elsevier. 272-304. https://doi.org/10.1016/B978-044451114-0/50016-8

Yorks, J. E., Hlavka, D. L., Vaughan, M. A., McGill, M. J., Hart, W. D., Rodier, S., \& Kuehn, R. (2011b). Airborne validation of cirrus cloud properties derived from CALIPSO lidar measurements: Spatial properties. Journal of Geophysical Research, 116, D19207. https://doi. org/10.1029/2011JD015942

Yorks, J. E., McGill, M., Hlavka, D., \& Hart, W. D. (2011a). Statistics of cloud optical properties from airborne lidar measurements. Journal of Atmospheric and Oceanic Technology, 28, 869- 883. https://doi.org/10.1175/2011JTECHA1507.1

Zeng, N., Qian, H., Roedenbeck, C., \& Heimann, M. (2005). Impact of 1998-2002 midlatitude drought and warming on terrestrial ecosystem and the global carbon cycle. Geophysical Research Letters, 32, L22709. https://doi.org/10.1029/2005gl024607

Zhao, C. L., \& Tans, P. P. (2006). Estimating uncertainty of the WMO mole fraction scale for carbon dioxide in air. Journal of Geophysical Research, 111, D08S09. https://doi.org/10.1029/2005JD006003

Zhou, Y., Williams, C. A., Lauvaux, T., Davis, K. J., Feng, S., Baker, I., et al. (2020). A multiyear gridded data ensemble of surface biogenic carbon fluxes for North America: Evaluation and analysis of results. Journal of Geophysical Research: Biogeosciences, 125(2), e2019JG005314. https://doi.org/10.1029/2019JG005314 